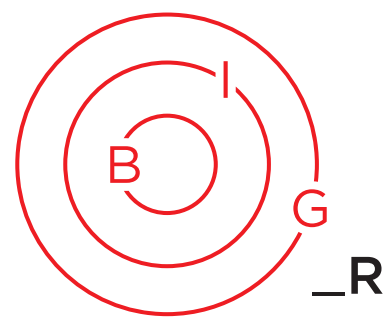

ESSAY

SPECIAL ISSUE

\title{
The Portuguese-Spanish Border ... Back Again?!
}

\author{
Iva Pires*
}

Unexpectedly, over 30 years after the removal of border controls between Portugal and Spain as a result of their joint adhesion to the European Union, border restrictions were reinstated as a preventive measure to contain the spread of the novel coronavirus (COVID-19). This paper discusses what has changed in the Portuguese-Spanish border as a consequence of the COVID-19 outbreak.

\section{Introduction}

After centuries of disputes, intense negotiations, and a final military conflict in 1801, the Convention on Border Limits (1926) ultimately defined the boundary between Portugal and Spain, despite the fact that a small section of about 54 kilometres in length still remains under dispute. The Portuguese-Spanish border-the only land border Portugal has-is 1,214 kilometres (754 miles) long. The dictatorial regimes that governed both countries until the mid-1970s maintained strict control on border crossings. Following the joint accession in the European Economic Community (EEC) in 1986renamed the European Union (EU) in the 1990s-the bilateral relations between the two countries were also

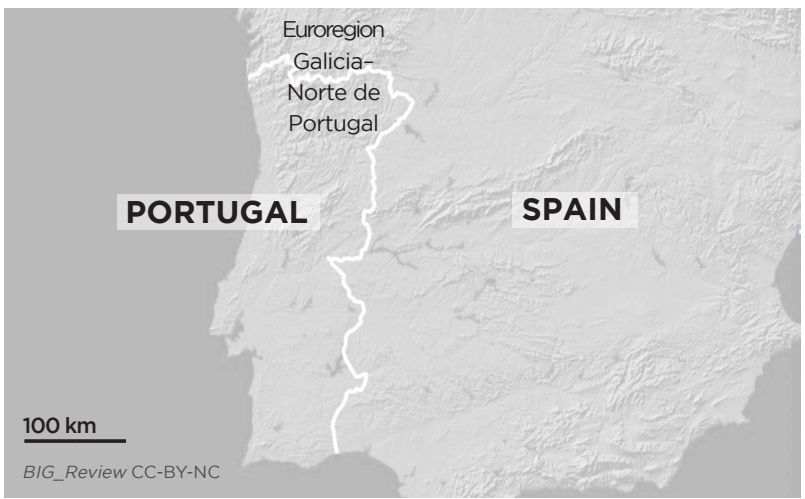

improved. The Single European Act, signed in 1986, leading to the creation of the 'Single Market' and the 'Schengen' agreements, to which both Iberian countries joined in 1995, allowed for the free flow of trade across EU borders and for people to travel without having their passports checked at the borders. This enhanced Spain and Portugal's political and economic relations. Spain became Portugal's main economic partner, and daily traffic across the border became significant, including the movement of cross-border workers, shopping trips, tourism and freight transportation.

Unexpectedly, over 30 years later, the border was closed again as a preventive measure to contain the spread of COVID-19. The control of land borders with Spain that started at 11 pm on 16 March 2020 and ended on 1 July halted all cross-border movements with only some exceptions.

This resolution, although temporary and justified in public health terms, was not well received by border communities. In a webinar on the closing of the borders Pablo Rivera, secretary general of the Iberian Network of Crossborder Bodies (RIET), commented "The population at the border (Raia Ibérica) is usually very close to each other and this decision ended up separating people and creating distrust in politicians".

\footnotetext{
* Iva Pires, Interdisciplinary Centre of Social Sciences (CICS.NOVA), Faculty of Social Sciences and Humanities (NOVA.FCSH),
} Universidade Nova de Lisboa, Portugal. Email: Im.pires@fcsh.unl.pt 


\section{The Border After EU Joint Accession}

Up until the joint accession to the EEC in 1986, and despite the fact that both countries were governed by similar dictatorships, movement across the border was not substantial. Border crossing required a special authorization and many citizens were not allowed to leave the country. Due to political restrictions many of these were forced to flee the country crossing the border illegally. There was considerable smuggling-in some sectors a relevant source of income and survival for impoverished border communities. The border was known as "the border of underdevelopment" as populations on either side were among the poorest of each country.

The context changed enormously after the joint EU accession, as obstacles to free movement of people and goods were removed and administrative control points decommissioned. Although occurring unequally among border regions, other direct consequences of the de-bordering process were the strengthening of political and economic relations, and an intensification of cross-border investments and trade flows.

Before the pandemic, around 79,000 vehicles crossed the border between Spain and Portugal every day (88\% light vehicles). Half of this traffic passed through the Euroregion Galicia-Norte de Portugal, considered a pioneer in promoting cross-border cooperation, and one of the most dynamic in cross-border flows, partly due to cultural and linguistic proximity. Intense traffic movement on the motorways connecting the two regions is part of the Euroregion's daily life-a consequence of strong institutional and economic cooperation. Labor commuting on a daily or weekly basis was also significant. Cross-border flows were also intense in the south part of the border, used by tourists to visit the Algarve and also as a gateway to agricultural products from Andalusia to Portugal.

Although development and flows are unequally distributed along the border, its opening brought benefits and its closure was felt by border communities as a severe penalization to their economies.

\section{What Changed After Borders were Closed?}

To protect the health and safety of EU citizens, Member States agreed on a set of priorities to coordinate the EU's response to COVID-19, which included closing schools, shops, restaurants, prohibited public gatherings and more than half have proclaimed a State of Emergency. This State of Emergency allowed for the introduction of border/travel restrictions within EU Member States based on the Free Movement of Persons, Services and Capital Chapter of the Treaty of Lisbon, on grounds of public policy, public security or public health.
France was the first European country to experience the pandemic, with three cases confirmed on 24 January 2020. In Spain the first two cases were detected on 30 January. After those first cases the virus spread quickly, with cases mainly imported from Northern Italy. Portugal's first cases were detected on 2 March, with two Portuguese citizens arriving from Italy. The spread of the virus was very slow until 10 March and then started growing exponentially.

On 16 March, due to the sanitary emergency, Portugal's and Spain's prime ministers held a videoconference to discuss and coordinate health control measures at the common borders (land, air, sea). On 19 March, Portugal declared a State of Emergency, which involved the closure of the border with Spain and confinement measures domestically to 'flatten the curve' of the pandemic's spread.

Portugal and Spain cooperated at the level of Ministers for Home Affairs and for Foreign Affairs in the elaboration of a set of technical notes that allowed the exceptional and temporary reintroduction of passport controls between them and the prohibition of road traffic on border checkpoints. Also flights to and from Spain, inland navigation and railway services were suspended (Council of Ministers' Resolution nำ-B/2020).

Traffic was strictly prohibited at the land border with the exception of nine Authorized Crossing Points (ACP) distributed along the border. Those entering and leaving Portugal and Spain through ACP would undergo health monitoring. On the Portuguese side, the Immigration and Borders Service (SEF) and the National Republican Guard (GNR) were responsible for controlling the border. Infrastructures of Portugal (IP), in collaboration with SEF and GNR, provided teams for the implementation of traffic control and signage, both for ACP as well as closed border crossings.

Circulation was allowed only for international freight operations, cross-border workers and seasonal workers with documents justifying their employment context, emergency and rescue vehicles, citizens and holders of residency permits in their respective countries.

The State of Emergency was decreed for 15 days, starting at 12:00 am on 19 March and ending at 11:59 pm on 2 April, 2020. However, it was renewed twice: between 3 April and 17 April; and a third period between 18 April and 2 May. On 3 May a State of Calamity replaced the State of Emergency allowing for the gradual reopening of the economy.

Nevertheless, both governments agreed on the extension of border controls affecting both land and air travel and the limitation to nine ACP on the land border at least until 15 May. These limitations were further extended until 30 June 2020. 
Borders in Globalization Review | Volume 2 | Issue 1 | Fall/Winter 2020

Pires, "The Portuguese-Spanish Border ... Back Again?!"

\section{The Reopening of the Borders}

A "joint European Roadmap towards lifting COVID-19 containment measures" was adopted to plan for a safe restart of economic and social activities in the EU. Spain opened its borders earlier than Portugal to EU travelers on 21 June, while the border with Portugal remained closed after the Portuguese Government requested more time to organize the reopening. Finally, on 1 July the Portuguese-Spanish land border was reopened, more than three months after it had been closed due to the outbreak.

Border communities experienced the reopening with mixed feelings. On the one hand, as Spain has been one of Europe's hardest-hit countries in the pandemic, some feared that it may lead to the spreading of the virus and an increase in the number of infected people. On the other hand, cross-border shopping and leisure travel were important activities for border economies and it was seen as an opportunity for business to recover after more than three months of stagnation.

Border regions have actually been working together to accelerate their much-needed economic recovery. In mid-May, when the reopening of the border was once again postponed, the mayors of the seven border Eurocities of Portugal and Spain came together to petition their governments to restart the free movement of people in these regions whose economies were severely affected by the closure. Specifically, they wanted their governments to decree the free movement of citizens within these Eurocities.

On 5 May the Eurocity Chaves-Verín organized a webinar on "Iberian Eurocities against COVID-19 crisis" that was attended by all the Iberian Eurocities. Later on, on 15 May, they released a "Manifesto of the seven Iberian Eurocities" urging restoration of the movement of people between these cities, to discuss a specific protocol for reopening and to promote them as safe regions on gastronomic, cultural, touristic and production levels.

Another example is Euroace, which brings together three regions (Centro and Alentejo on the Portuguese side and Extremadura in Spain), and plans to organize a cross-border promotion strategy directed towards the potential market of 55 million inhabitants of both countries. By presenting itself as a peaceful and safe destination for the first post-COVID-19 holiday destinations they aimed to accelerate the recovery of tourist activity as soon as the mobility between the two countries is restarted.

The reopening was celebrated by special ceremonies that took place in the border towns of Elvas and Badajoz. Spain's King Felipe VI and Prime Minister Pedro Sánchez met with Portuguese President Marcelo
Rebelo de Sousa and Prime Minister António Costa in Badajoz on the Spanish side and later in Elvas, Portugal, for lunch.

The desire to maintain a coordinated response during the second outbreak was announced by the Portuguese Minister for Foreign Affairs with his Spanish counterpart during the preparation of the PortugueseSpanish Summit scheduled for October 2020. At that summit, the reopening of railway communications and a common cross-border strategy to support the recovery of the most affected border economies were to be be discussed, among other topics.

\section{Borders were Closed However...}

A peculiar exception to the closing of the border was commonly agreed upon between the Portuguese and the Spanish governments relating to two small villages in the Northern strip, Rio de Onor (Portugal) and Rihonor de Castilha (Spain), separated by a small river. With 14 people living on the Spanish side and 50 on the Portuguese side, the interaction had been so intense inhabitants felt they lived in the same village. Small-scale farming and cattle raising were the most important activities and most inhabitants held properties on both sides of the border. When the closure of the border was decided the population complained that, even in the past, when borders were tightly controlled, their inhabitants had never been prevented from moving between villages, partially due to the isolation and distance to the power centers in Lisbon and Madrid.

While the walking trips between the two villages remained a part of daily life, motor circulation (including agricultural equipment) was forbidden when the borders were closed and the nine ACPs that remained open were not an option as they were too far away. Therefore, both governments agreed on making an exception to the peculiar reality of these villages and permitted farmers to cross the border on Wednesdays and Saturdays for two hours between 9 am and $11 \mathrm{am}$, to feed their animals and farm their lands.

\section{Conclusion}

To contain the spreading of the virus, on 19 March Portugal and Spain agreed to apply an initial 15 days coordinated restriction of non-essential travel at the borders. That period was successively extended and the border only reopened on 1 July.

The measures related to the closure of borders (land, sea and air) were taken in a coordinated manner between the two countries and were globally well received, despite being experienced by border communities as a severe hardship. However, given 
that Spain was one of the EU countries hardest hit by the new virus health interests prevailed over economic ones. The closing of the borders and the strict limitations to citizen's mobility helped to prevent the spread of COVID-19 and in Portugal the number of cases remained considerably lower than in the neighbouring country. Also the reopening was well coordinated both at state level and at local level with cross-border initiatives.

Despite combating the spread of the virus, the closure of borders was assumed to be exceptional and only temporary as the Portuguese Prime Minister aptly tweeted "The pandemic offered us the vision of a past we don't want to go back to: a continent with closed borders."
This situation also brings to the fore relevant questions in the field of cross-border cooperation, as it is in times of crisis that we notice the underlying attitude between these neighbours: if negotiations since 1986 have always sought the opening of the border, it was the same conciliatory spirit that argued for its closure in this case.

\section{Acknowledgements}

This work is financed by national funds through FCT Foundation for Science and Technology, I.P., within the scope of the project «UIDB / 04647/2020» of CICS. NOVA - Centro Interdisciplinar de Ciências Sociais da Universidade Nova de Lisboa. 